\title{
MENGKAJI KLONING MANUSIA DARI PERSPEKTIF HUKUM KODRAT
}

\author{
Oleh: \\ Zainal Fadri* \\ Institut Agama Islam Negeri Batusangkar \\ zainalfadri@iainbatusangkar.ac.id
}

\begin{abstract}
Cloning has become a hot topic since technology activists in the field of genetics explained the results of their research that the reproductive process can occur with the help of technology. People have taken advantage of the results of this technology, although the debate about its use in humans is still not a comprehensive concept. This study aims to assess the extent to which the human cloning program is viewed from natural law, considering that cloning is an activity to bring back humans who have died. The method used in this research is literature review with a holistic analysis of the natural law view of human cloning. The results of this research indicate that the human cloning program is returned to the beneficiaries of this program and is fully responsible for the decisions taken
\end{abstract}

Keywords: Human Cloning, Natural Law

\section{A. PENDAHULUAN}

manusia. Dengan hadir nya berbagai temuan yang memanjakan manusia seolah-olah segala hal ingin diciptakan manusia dalam mencapai kepuasan dan kebahagiaan hidup. Mulai dari teknologi kecil hingga teknologi yang berdampak besar bagi kehidupan di muka bumi. Salah satu teknologi yang menjadi perincangan hingga saat ini yaitu hadirnya teknologi kloning ditengah kehidupan masykarat.

Pada prinsipnya manusia bebas dalam menentukan arah hidupnya. Namun semua gerak gerik manusia juga dibatasi oleh kebebasan teman-teman manusia lainnya. Tidak bisa dibenarkan bahwa manusia bebas dengan sebebas-bebasnya sehingga tidak ada ruang bagi kebebasan orang lain. Inilah yang dinamakan dan konsekuensi paling besar bagi etika (Bertens, 2011: 129), alasan utama diberlakukan suatu tatanan moral di antara manusia.

Permasalahan kloning hingga saat ini masih menuai pro dan kontra dari berbagai pihak. Pro kontra ini terjadi karena masih banyaknya perdebatan dikalangan saintis maupun agamawan serta moralis dengan idealisme nya masingmasing. Namun permasalahan yang terbesar adalah bagaimana teknologi kloning berkembang dalam 
kehidupan msyarakat, disini muncullah persoalan bagaimana menyikapi perkembangan teknologi kloning tentunya dengan tetap berpijakan pada norma-norma yang telah melekat dimasyarakat dan tentunya dengan pertimbangan yang benar-benar teruji.

Pada makalah ini akan dipaparkan teknologi kloning ditinjau dari hukum kodrat. Hukum kodrat disini akan melihat bagaimana hubungan antara kloning dengan kodrat kemanusiaan manusia sendiri. Dari sini diharapakan ada gambaran bagaimana posisi teknologi kloning dalam kehidupan manusia.

\section{B. PEMBAHASAN}

\section{Teknologi Kloning Manusia}

Istilah "kloning" adalah khas dalam bidang biologi, berasal dari kata clone atau klon (Indonesia) yang berarti kumpulan sel turunan dari sel induk tunggal dengan reproduksi seksual (KBBI, 1991: 509). Menurut sebagian ahli biokimia dan biologi, kloning merupakan istilah umum yang digunakan untuk menghasilkan atau memperoleh individu yang persis sama dengan induknya. Individu yang dihasilkan melalui kloning biasanya disebut klon (clone).

Secara etimologis kloning berasal dari kata clone, yang diturunkan dari bahasa Yunani "klon", artinya potongan yang digunakan untuk memperbanyak tanaman. Namun secara terminologis, kloning adalah proses pembuatan sejumlah besar sel atau molekul yang seluruhnya identik dengan molekul asalnya. Kloning dalam bidang genetika merupakan replikasi segmen DNA melalui proses seksual. Itulah sebabnya kloning juga dikenal dengan istilah rekombinasi DNA. Rekombinasi DNA membuka peluang baru dalam terobosan teknologi untuk mengubah fungsi dan perilaku makhluk hidup sesuai dengan keinginan dan kebutuhan manusia (Daulay, 2005: 41).

Metode kloning berbeda dengan metode pembuahan biasa, karena sel telur tidak lagi memerlukan sel sperma untuk pembuahannya. Secara sederhana dapat disebut bahwa bayi klon dibuat dengan mempersiapkan sel telur yang sudah diambil intinya kemudian digabungkan dengan sel donor yang merupakan sel dewasa dari suatu organ tubuh. Hasil gabungan tersebut kemudian ditanamkan ke dalam rahim dan dibiarkan berkembang dalam rahim sampai lahir.

Secara teoritis teknik kloning kelahiran seorang bayi tidak lagi memerlukan sperma ayah. Bahkan seorang perempuan dapat memiliki anak tanpa melalui ikatan perkawinan. Demikian juga dengan seorang laki-laki apabila ingin punya anak tidak perlu beristri. Cukup hanya dengan memesan sel telur pada suatu firma, memberikan selnya dari salah satu organ tubuhnya dan kemudian menitip calon anaknya pada rahim seorang wanita yang bisa jadi telah disediakan oleh firmanya tersebut (Daulay, 2005: 42). Namun kloning yang dilakukan tidaklah sesederhana itu tapi ia memiliki prosedur dan mekanisme yang cukup rumit untuk dijelaskan, terutama bagi kaum non eksakta dan non biologi. 
2. Prosedur dan Mekanisme Kloning Manusia

Secara teoritis, prosedur dan mekanisme kloning terhadap makhluk hidup sedikitnya harus melalui empat tahap yang diurutkan secara sistematis. Keempat tahap ini adalah isolasi frgamen DNA, Penyisipan Fragmen DNA ke dalam vektor, transformasi dan seleksi hasil kloning. Keempat tahap tersebut akan dijelaskan (Daulay, 2005: 52-55) yaitu:

\section{a. Isolasi fragmen DNA}

Isolasi fragmen DNA yang spesifik dapat dilakukan dengan metode PCR (Polymerase Chain Rection), yaitu teknik aplikasi fragmen DNA yang spesifik secara invitro. Umumnya DNA yang digunakan untuk PCR adalah total DNA genom yang diekstraksi dari sel dan tidak membutuhkan tingkat kemurnian tinggi. Urutan DNA yang spesifik akan ditentukan oleh primerprimer yang tersusun dari nukleotida. Konsentrasi nukleotida yang digunakan adalah 1 iM dan dapat digunakan untuk sedikitnya 30 siklus aplikasi. Produk PCR merupakan molekul DNA untai ganda berujung tumpul dan dapat dikloning ke dalam vektor standar dengan teknik konvensional.

Material yang diperlukan untuk proses PCR adalah DNA yang mengandung rangkaian untaian yang akan diperbanyak, yaitu primer, DNA polimerase, dan campuran dari empat macam deosiribonukleotida-trifosfat. Kondisi reaksi yang terjadi mencakup penentuan waktu, suhu, dan jumlah siklus tergantung pada duplikasi
DNA yang akan diamplikasi serta peimer yang digunakan.

b. Penyisipan fragmen DNA ke dalam vektor

Proses penyisipan atau penyambungan molekul fragmen DNA dengan melalui molekul DNA vektor disebut lingan. Legasi terjadi antara ujung fosfat dengan gugus hisroskil. Legasi antara fragmen DNA yang memiliki ujung lengket atau yang komplementer jauh lebih efisien dibandingkan dengan ujung tumpul. Efisiensi legasi juga dipengaruhi oleh deoksidenosin tunggal pada ujung bertemu dengan vektor yang memiliki timidin pada ujung. Deoksidenosi tunggal pada ujung fragmen DNA dapat dihasilkan dari PCR yang menggunakan enzim DNA polimerase tag.

\section{c. Transformasi}

Vektor kloning yang merupakan bawaan gen yang akan dikloning ditransformasi ke dalam inang. Transformasi adalah proses pemindahan molekul DNA donor dari lingkungan luar sel. Transformasi dapat dilakukan secara alami atau buatan. Pada proses transformasi alami, DNA yang berbentuk untai ganda dan memiliki untaian basa spesifik terhadap protein membran masuk ke dalam bakteri melewati membran bakteri terhidrolisis. Pada transformasi buatan sel bakteri dibuat menjadi sel kompeten secara paksa sehingga selubung sel bakteri bersifat permeabel dan memungkinkan DNA dapat berikatan dengan sel yang masuk ke dalam sitoplasma, kemudian berinteraksi dengan gonom sel bakteri. 
Metode transformasi buatan untuk sel inang dan spesies E. coli mencakup pembuatan sel kompeten dan perlakuan untuk memasukkan DNA ke dalam sel kompeten. Sel kompeten adalah sel inang yang memiliki kompetensi untuk dimasuki vektor kloning. Perlakuan untuk memasukkan sel DNA ke dalam sel kompeten dapat digunakan dengan metode kejutan panas (heat shock) atau kejutan pada listrik yang disebut metode electroporation.

\section{d. Seleksi hasil kloning}

Penyelesaian koloni bakteri untuk mendapatkan kloning yang diinginkan dapat dilakukan dengan cara antara lain, dengan X-gal atau pemotongan dengan enzim retriksi. Seleksi dengan X-gal dapat digunakan untuk mengidentifikasi plasmid rekombinan hasil kloning. Hasil potongan tersebut dielektroforesis dan memperlihatkan pita fragmen DNA sisipan yang terpisah dari pita vektor kloning.

Dalam tataran aplikasi,
rentetan proses kloning dapat
dilakukan dengan mengikuti beberapa langkah konkrit berikut: (1) Mempersiapkan sel stem, yaitu suatu sel awal yang akan tumbuh menjadi berbagai sel tubuh. Sel ini diambil dari makhluk hidup yang hendak dikloning. (2) Sel stem diambil inti selnya yang mengandung informasi genetik kemudian dipisahkan dari sel. (3) Mempersiapkan sel telur, yaitu sebuah sel yang diambil dari makhluk hidup dewasa kemudian intinya dipisahkan. (4) Inti sel dari sel stem diimplimentasikan ke sel telur. (5) Sel telur dipicu supaya terjadi pembelahan dan pertumbuhan.
Setelah membelah menjadi embrio. (6) Sel embrio yang terus membelah (disebut blastosis) mulai memisahkan diri dan siap diimplementasikan ke dalam rahim. (7) Embrio tumbuh dalam rahim menjadi janin dengan kode genetik persis sama dengan sel stem donor (Dulay, 2005: 56).

Ditinjau dari cara kerja dan tujuannya, kloning dapat dibedakan menjadi tiga macam, yaitu kloning embrional (embryonal cloning), kloning DNA dewasa (adult DNA cloning), dan kloning terpeutik (therapeutic clonig).

Kloning embrional adalah
kloning yang dilakukan untuk memperoleh kembar identik, meniru apa yang terjadi secara alamiah. Setelah pembuahan terjadi, beberapa sel dipisahkan dari embrio hasil pembuahan. Setiap sel tersebut kemudian dirangsang dalam kondisi tertentu untuk tumbuh dan berkembang menjadi embrio duplikat dan selanjutnya diimplementasikan dalam uterus agar berkembang menjadi induvidu baru yang memiliki komposisi materi genetik yang sama dengan klonnya.

Sementara itu, kloning DNA dewasa atau kloning reproduktif adalah rekayasa genetik untuk memperoleh duplikat dari seorang individu yang sudah eksis. Dalam teknologi ini, sel inti berisi materi genetik difusikan ke dalam sel telur. Hasil fusi ini dirangsang dengan kejutan listrik agar membelah membentuk embrio kemudian diimpelmentasikan ke dalam uterus agar berkembang menjadi janin. 
Sedangkan kloning therapeutic adalah rekayasa genetis untuk memperoleh sel, jaringan atau organ dari suatu individu tertentu dengan tujuan pengobatan atau perbaikan kesehatan. Dari embrio hasil rekonstruksi DNA sel telur, diambil sel-sel bekalnya yang disebut stem cell. Stem cell adalah sel bakal yang dapat berkembang menjadi berbagai macam jaringan atau organ yang sesuai dengan induktor (rangsangan) yang diberikan (Daulay, 2005:58).

Walaupun berkembang menjadi jaringan yang berbeda-beda, namun sel yang berasal dari stem cell yang sama memiliki sifat genetik yang sama pula, sehingga ketika diimplementasikan pada individu yang menjadi donor DNA-nya, maka resiko penolakan secara teoritis hampir tidak ada. Sebagaimana yang diketahui resiko penolakan adalah masalah terbesar yang dihadapi pada transplanatasi jaringan atau organ konvensional.

\section{Hukum Kodrat Thomas Aquinas}

Thomas Aquinas (1225, Aquino, Italia - Fossanova, Italia, 7 Maret 1274), kadangkala juga disebut Thomas dari Aquino (bahasa Italia: Tommaso d'Aquino) adalah seorang filsuf dan ahli teologi ternama dari Italia. Ia terutama menjadi terkenal karena dapat membuat sintesis dari filsafat Aristoteles dan ajaran Gereja Kristen. Sintesisnya ini termuat dalam karya utamanya: Summa Theologiae (1273). Ia disebut sebagai "Ahli teologi utama orang Kristen." Bahkan ia dianggap sebagai orang suci oleh Gereja Katholik dan memiliki gelar santo.

Aquinas merupakan teolog skolastik yang terbesar. Ia adalah murid Albertus Magnus. Albertus mengajarkan kepadanya filsafat Aristoteles sehingga ia sangat mahir dalam filsafat itu. Pandanganpandangan filsafat Aristoteles diselaraskannya dengan pandanganpandangan Alkitab. Ia lah yang sangat berhasil menyelaraskan keduanya sehingga filsafat Aristoteles tidak menjadi unsur yang berbahaya bagi iman Kristen. Pada tahun 1879, ajaran-ajarannya dijadikan sebagai ajaran yang sah dalam Gereja Katolik Roma oleh Paus Leo XIII.

Thomas dilahirkan di Roccasecca, dekat Aquino, Italia, tahun 1225. Ayahnya merupakan Pangeran Landulf dari Aquino. Orang tuanya adalah orang Kristen Katolik yang saleh. Itulah sebabnya Thomas, pada umur lima tahun, diserahkan ke biara Benedictus di Monte Cassino untuk dibina agar kelak menjadi seorang biarawan. Setelah sepuluh tahun Thomas berada di Monte Cassino, ia dipindahkan ke Naples untuk menyelesaikan pendidikan bahasa. Selama di sana, ia mulai tertarik kepada pekerjaan kerasulan gereja, dan ia berusaha untuk pindah ke Ordo Dominikan, suatu ordo yang sangat berperanan pada abad itu. Keinginannya tidak direstui oleh orang tuanya sehingga ia harus tinggal di Roccasecca setahun lebih lamanya. Namun tekadnya sudah bulat sehingga orang tuanya menyerah kepada keinginan anaknya. Pada tahun 1245, Thomas resmi menjadi anggota Ordo Dominikan. 
Sebagai anggota Ordo Dominikan, Thomas dikirim belajar pada Universitas Paris, sebuah universitas yang sangat terkemuka pada masa itu. Ia belajar di sana selama tiga tahun (1245 -- 1248). Di sinilah ia berkenalan dengan Albertus Magnus yang memperkenalkan filsafat Aristoteles kepadanya. Ia menemani Albertus Magnus memberikan kuliah di Studium Generale di Cologne, Perancis, pada tahun 1248 - 1252. Pada tahun 1252, ia kembali ke Paris dan mulai memberi kuliah Biblika (1252-1254) dan Sentences, karangan Petrus Abelardus (1254-1256) di Konven St. Jacques, Paris.

Kecakapan Thomas sangat terkenal sehingga ia ditugaskan untuk memberikan kuliah-kuliah dalam bidang filsafat dan teologia di beberapa kota di Italia, seperti di Anagni, Orvieto, Roma, dan Viterbo, selama sepuluh tahun lamanya. Pada tahun 1269, Thomas dipanggil kembali ke Paris. Ia hanya tiga tahun berada di sana karena pada tahun 1272 ia ditugaskan untuk membuka sebuah sekolah Dominikan di Naples. Dalam perjalanan menuju ke Konsili Lyons, tiba-tiba Thomas sakit dan meninggal di biara Fossanuova, 7 Maret 1274. Paus Yohanes XXII mengangkat Thomas sebagai orang kudus pada tahun 1323 .

Hukum kodrat adalah perwujudan dari kebijaksanaan atau rencana abadi dalam kodrat manusia, khususnya dilihat dari segi ciptaan. Hukum kodrat disini tidak lain adalah cara pengungkapan ciptaan seturut rencana ilahi yang abadi, dan dengan demikian pengungkapan partisipasi dalam hukum abadi, dengan cara hidup yang sesuai dengan kodratnya. Dengan demikian seperti halnya Aristoteles, bagi Thomas Aquinas pun hidup yang baik adalah hidup yang sesuai dengan kodratnya sendiri yang bersifat niscaya. Hidup yang sesuai dengan kodrat adalah hidup yang baik karena hidup sesuai dengan kodratnya manusia telah ikut ambil bagian dalam rencana ilahi (Keraf, 1997: 21).

Thomas melihat bahwa hukum kodrat bagi manusia bukanlah suatu kekuatan buatan yang memaksa. Karena menuurut Thomas, hukum kodrat tidak lain adalah hukum akal budi, dan karena itu hanya bagi makhluk yang rasional. Jadi hukum kodrat lebih merupakan hukum yang rasional. Thomas berpandangan bahwa "hukum kodrat tidak lain adalah partisipasi makhluk rasional dalam hukum abadi". Dengan kata lain, pada prinsipnya hukum kodrat telah ditemukan dalam hukum abadi dan baru kemudian ditemukan dalam perkembangan kodrati manusia dengan akal budinya (Keraf, 1997: 22). Ini berarti manusia hanya bisa tunduk pada hukum kodrat sejauh mana manusia itu ikut ambil bagian dalam hukum abadi melalui refleksi akal budinya.

Manusia diberi hukum kodrat karena manusia mampu berfikir, bertindak menurut hukum kodrat atau sesuai dengan kodrat manusia, tidak lain berarti bertindak melalui akal budinya, termasuk dengan menggapai secara rasional semua kecenderungan kodratinya yang lain. Thomas juga mengatakan "segala sesuatu, ke arah mana manusia mempunyai kecenderungan alamiah, dianggap sebagai hal yang baik oleh akal budi, 
dan karena itu berbagai sesuatu harus dikejar dalam tindakan, dan hal-hal yang bertentangan dengannya harus dihindari". Demikian pula "seperti halnya akal budi adalah hal yang dominan dalam diri manusia dan mengendalikan semua kekuatan lainnya, demikian pula kecenderungan alamiah yang melekat pada kekuatan lainnya dikendalikan oleh akal budi. Karena itu di antara semua orang yang umumnya benar adalah bahwa kecenderungan semua manusia harus diarahkan oleh akal budi" (Keraf, 1997: 22).

Dengan ini dalam pemikiran Thomas telah ditemukan legitimasi daripada hukum kodrat. Hukum kodrat menemukan legitimasinya pada hukum abadi sebagai kehendak dan rencana Pencipta. Dipihak lain sebagai makhluk yang secara kodrati diberikan akal budi, hukum kodrat menemukan legitimasinya pada refleksi kritis manusia yang mewajibkannya untuk bertindak secara tertentu karena memang hal itu baik bagi penyempurnaan dan kelangsungan hidupnya.

Thomas juga membedakan antara hukum kodrat primer dengan hukum kodrat sekunder. Hukum kodrat perimer terdiri atas prinsipprinsip moral yang paling umum beralaskan stuktur-struktur kemanusiaan yang hakiki, karena itu berlaku mutlak dan tidak dapat berubah. Adapun hukum kodrat sekunder adalah ketentuan moral yang merupakan penerapan prinsip moral paling umum tadi dalam perkembangan hidup manusia dalam masyarakat tertentu (Keraf, 1997: 23).
Selain itu Thomas juga mengatakan bahwa kecenderungankecenderungan dasar yang sekaligus menjadi hukum kodrat bagi manusia adalah menjaga dan mempertahankan kehidupan pribadi dan hal-hal yang berkaitan dengan itu adalah melakukan hubungan seksual demi reproduksi, menjaga dan mendidik anak cucu, mengatahui kebenaran tentang Tuhan dan hidup di dalam masyarakat. Singkatnya manusia dianugerahi tiga kewajiban dasar yang menjadi kandungan utama hukum kodrat, yaitu mempertahankan kehidupan pribadi, mengetahui kebenaran tentang Tuhan, dan mempertahankan hidup bersama dengan orang lain dalam masyarakat.

Secara khusus mengenai kecenderungan terakhir, menurut Thomas masyarakat manusia sesungguhnya telah berakar dalam hakikat manusia. Secara kodrati manusia adalah makhluk individual yang sosial. Hakikat sosial ini sangat penting bagi kesempurnaan hidupnya, baik hidup rasional, moral, maupun spiritual (Keraf, 1997: 24).

\section{Kontroversi Seputar Kloning}

Kloning, terutama kloning pada manusia agaknya lebih banyak memiliki implikasi agama dan etika dari pada teknologi. Hal ini dibuktikan dengan banyaknya tokohtokoh agama dan kaum moralis yang membuktikan bahwa kloning tidak berdiri sendiri sebagai sebuah ilmu pengetahuan, ia juga bersentuhan dengan masyarakat, budaya dan agama. Dalam merspon kebearadaan kloning pada manusia para tokoh agama dan etika dibeberapa belahan 
dunia, memiliki pendapat-pendapat, baik dari yang kontra (menentang temuan kloning secara mutlak maupun dengan syarat) maupun yang pro (dengan cara memilah dan menyeleksi jenis dan proses kerja kloning sebagai temuan besar dan anugrah Tuhan bagi manusia).

Di antara yang kontra dapat dilihat misalnya sebagian institusiinstitusi besar agam seperti Vatikan dan al-Azhar menyoroti permasalahan ini dengan sensitif bahkan cenderung reaksioner (Alkaf, 2003: 10). Teknologi kloning menunjukkan kurangnya penghormatan manusia terhadap mahkluk hidup. Manusia diciptakan dari citra Tuhan dan kloning hendak mengotori hal tersebut. Tanggapan senada juga diungkapkan dari beberapa muslim di Amerika, mereka mengatakan bahwa teknologi kloning hanya akan menurunkan institusi perkawinan. Sedangkan pusat fiqih Islam mengadakan sidang di Saudi Arabia, menetapkan keharaman kloning reproduksi manusia dengan cara apapun. Pusat ini juga mengahramkan semua hal yang melibatkan pihak ketiga dalam hubungan perkawinan, baik keterlibatan rahim saja atau keterlibatan sperma, ovum, atau sel pada bagian tubuh untuk digunakan dalam proses kloning.

Namun demikian, tidak semua tokoh agama dan etika mengaharamkan atau melarang kloning. Di antara mereka ada yang bersifat moderat, dengan cara mencermati lebih dulu jenis dan proses kerja yang ada pada kloning. Mereka yang pro berpendapat lebih pada tujuan dari pada kloning yang dibolehkan seperti pencegahan penyakit dan mempertahankan kesehatan. Selain alasan kesehatan alasan lainnya adalah kloning bukan berarti manusia ikut campur terhadap ciptaan Tuhan. Ilmuan tetap manusia dan ciptaan Tuhan (Alkaf, 2003: 14$15)$.

Permasalahan yang digambarkan dalam kloning lebih kepada bagaimana manusia tetap menjaga sikap manusiawi terhadap seluruh pencapaian teknologi. Inilah mungkin yang mendorong kaum moralis dan agamawan bersikap curiga terhadap teknologi kloning. Lebih dari itu mayoritas manusia yang ada di dunia ini sering dikendalikan oleh kenikmatan duniawi sehingga keberadaan kloning diyakini lebih banyak memperburuk wajah dunia daripada mempercantiknya.

\section{Gambaran Masa Depan Teknologi Kloning}

Meskipun banyak pro-kontra mengenai masalah kloning ini, terutama yang menentang baik secara keras maupun dengan cara tidak langsung, kloning diperkirakan tidak akan berakhir begitu saja. berbagai manfaat dan keuntungan yang dijanjikan melalui teknologi ini menyebabkan ia akan tetap dikaji dan disempurnakan oleh saintis. Salah satu jenis manfaat yang dapat ditemukan adalah bahwa teknologi kloning merupakan teknologi yang sangat potensial dan prosfektif untuk diaplikasikan dibidang kedokteran dan peternakan. Misalnya dengan adanya transfer inti serta rekayasa genetika untuk menyelesikan masalah kesehatan seperti alzeimer, parkison, 
dan penyakit-penyakit genetis lainnya, bahkan AIDS.

Pada hakikatnya penyakitpenyakit tersebut adalah dianggap penyakit yang sudah tidak mungkin disembuhkan karena adanya kerusakan permanen dalam sel-sel tubuh manusia. Beberapa peneliti berspekulasi apabila seseorag membutuhkan transplantasi sumsum tulang belakang untuk menyembuhkan kankernya, maka kemungkinan akan sulit untuk mendapatkan donor yag mempunyai genetis sesuai. Kesulitan ini dapat diatasi dengan menggunakan kombinasi teknologi transfer inti dan rekayasa genetik, dengan memanfaatkan sel telur yang telah dienukleasi dan digantikan dengan materi genetik yang sesuai, maka hanya dalam beberapa hari dia akan mendapat stem sel yang sesuai untuk ditransplantasikan kepada pasien tersebut.

Selain itu, kloning juga menjanjikan keuntungan (Daulay, 2005: 63-64) di antaranya: (1) Proses pembuahan yang dilakukan melalui teknologi ini dapat menolong pasangan-pasangan yang tidak subur untuk memperoleh keturunan, meskipun dianggap belum berhasil secara maksimal, namun harapan yang dijanjikan tetap menarik minat pasangan-pasangan tersbut. Dengan teknologi kloning manusia harapan mereka secara psikis dan emosional akan lebih besar dari masa-masa sebelumnya. (2) Manusia dapat mengkloning ginjal untuk kebutuhan pencakokan ginjal bagi mereka yang mengalami gagal ginjal. (3) Menusia juga dapat mengkloning tulang sumsum untuk anak-anak dan dewasa untuk mengobati penyakit leukimia. (4) Melalui kloning, manusia dapat mempelajari bagaimana menghidupkan dan mematikan sel. Dengan semikian kloning dapat membantu mengobati penyakit kanker yang menggerogoti sel-sel manusia. (5) Dengan kloning, manusia dapat memproduksi secara efektif terapi genetika untuk melawan penyakit kusta. (6) Melalui kloning, manusia dapat mempelajari pertumbuhan urat syaraf tulang belakang ketika mengalami gangguan. Dengan teknologi ini mereka yang tadinya duduk di kursi roda dapat disembuhkan dan sanggup untuk berjalan kembali. Teknologi kloning dapat digunakan untuk mengobati penyakit yang disebabkan oleh kelainan genetis pada manusia.

Dari sekian banyak pro dan kontra yang terjadi dalam menanggapi hadirnya teknologi kloning ini dalam masyarakat tentunya merupakan permasalahan yang harus diselesaikan secara moril. Moril disini sangat erat kaitannya dengan peran manusia sebagai kodrat manusia itu sendiri.

Hukum kodrat menanggapi hal ini dengan mengembalikan pada manusia dan kodratnya sendiri. Apakah teknologi ini digunakan dan bagaimana menggunakan serta untuk apa teknologi ini digunakan. Dengan pernyataan-pernyataan seperti ini jelas tergambar bahwa persoalannya bukan masalah apakah teknologi kloning ini baik atau buruk atau bahkan apakah teknologi kloning ini diperbolehkan oleh hukum kodrat manusia, namun persoalan yang sesungguhnya terletak pada untuk apa 
dan untuk siapa teknologi ini digunakan. Jelas salah jika teknologi ini digunakan untuk perbuatan tanpa batas, dengan kata lain melampaui hakikat kodrat manusia sendiri. Namun apakah ada sanggahan lagi ketika teknologi ini digunakan untuk menolong orang banyak menyelasaikan permasalahan kesehatan dan merupakan salah satu cara manusia untuk mempertahankan hidupnya. Maka yang harus digarisbawahi adalah persoalan kloning bukanlah persoalan boleh atau tidak semata, tapi lebih pada persoalan manusia dan hakikat kodrat manusia sebagai makhluk individu, sosial dan makhluk Tuhan.

\section{Daftar Kepustakaan}

Alkaf, H. (2003). Kloning dan Bayi Tabung. Jakarta: KAS.

Bertens, K. (2011). Etika. Jakarta: PT Gramedia Pustaka Utama.

Chang, W. (2009). Bioetika: Sebuah Pengantar. Yogyakarta: Kanisius.

Daulay, S. P. \& Siregar, M. (2005). Kloning dalam Perspektif Islam. Bandung: MMU.

Diane, W. (2008). Wedding Vows. US: ReaHowYouWant.

Ebrahim, A. F. M. (1997). Isu-isu Biomedis dalam Perspektif Islam. Bandung: Penerbit Mizan.

\section{KESIMPULAN}

Kloning merupakan suatu teknologi dalam menghadirkan makhluk (individu) baru identik dengan induknya tanpa adanya hubungan perkawinan sebelumnya. Hukum kodrat mengembalikan manusia pada kodrat kemanusiaannya. Manusia adalah makhluk individual yang sosial dan makhluk Tuhan sebagai citra dari kodrat Pencipta. Permasalahan teknologi kloning terletak pada bagaimana manusia menggunakan teknologi ini dalam kehidupan nyata. Keputusan moral yang diambil tersebut merupakan pokok yang menjadi kajian bagi manusia lainnya apakah langkah yang diambi sesuai dengan moril atau bertentangan.

Haryatmoko. (2009) "Proses Mediasi Ke Moment Moral", dalam "Pemahaman Diri" Ricoeur dan "Penampakan Wajah" Levinas, dalam jurnal Studia Philoso-phica et Theologica, Vol 9 No 2, Ok-tober 2009

Ikhsanudin, M.. (2005). Jika Ulama Mengkaji Aborsi. Yogyakarta: PSKK UGM.

Keraf, S. A. (1997). Hukum Kodrat dan Teori Hak Milik Pribadi. Yogyakarta: Kanisius.

Martin, M. W. (1994). Etika Rekayasa. Jakarta: PT Gramedia Pustaka Utama.

Ricoeur, P. (2008). Hermeneutika Ilmu Sosial, penj: Muhammad Syukri. Yogyakarta: Kreasi Wacana. 
89 Jurnal A1-Aqidah: Jurnal Ilmu Aqidah Filsafat, Volume 12, Edisi 2, Desember 2020

Salim. (1993). Bayi Tabung: tinjauan spek hukum. Jakarta: Sinar Grafika.

Sumaryono, E. (1999). Hermeneutik, Sebuah Metode Filsafat. Yogyakarta: Kanisius.

Supardan. (1996). Ilmu, Teknologi dan Etika. Jakarta: Gunung Mulia.
Ziegler, R. (2006). Saat Manusia Kloning Berkuasa (judul asli: Perfect Geklont, terj. Ivan Setiwan). Jakarta: PP Obor.

Zubair, A. C. (1990). Kuliah Etika. Jakarta: Rajawali.

Zubair, A. C. (1992). Etika Rekayasa Menurut Konsep Islam. Yogyakarta: Pustaka Pelajar. 